\title{
Characteristics of pathogenic bacteria isolates associated with the gut and gill of molluscan shellfish, Eastern Cape, South Africa
}

\section{Elizabeth Bosede Famewo ${ }^{1}$, Anthony Jide Afolayan ${ }^{1}$}

\section{Abstract}

Introduction: Infectious diseases attributable to the consumption of raw and lightly cooked molluscan shellfish are caused by bacterial agents that are associated either with human waste disposed into the ocean or those of marine origin. This has led to the increase in prevalence of bacterial agents and microbial resistance to antibiotics.

Method: Samples of Perna perna L. were dissected and homogenized for bacterial isolation. Six types of bacteria were isolated, identified and evaluated for their antimicrobial susceptibility profiling

Results: The microbial counts obtained revealed significant differences in the pathogenic bacteria populations found in the gut and gill of Perna perna. The morphological characteristics of the isolates were found to be of different shapes. All the isolates were catalase positive and oxidase negative except Vibrio spp. which was positive to the latter. Chloramphenicol and ciprofloxacin were the most effective antibiotics against all the isolates, each exhibiting 100\% efficacy. The highest resistance to ampicillin was observed in Salmonella spp., Shigella spp., Listeria monocytogenes and Staphylococcus xylosus.

Conclusions: The results of this study revealed that marine habitats are reservoirs of bacterial pathogens and there is increased resistance to antibiotics, thereby constituting risks to public health. Therefore, appropriate surveillance measures to safeguard the health of shellfish consumers' should be established.
1 Medicinal Plants and Economic Development (MPED) Research Niche Area. Faculty of Science and Agriculture, University of Fort Hare, Alice 5700, South Africa

Contact information:

Anthony Jide Afolayan.

Address: Faculty of Science and Agriculture, University of Fort Hare, Alice 5700 , South Africa.

Tel: +27 822022167

झ aafolayan@ufh.ac.za 


\section{Introduction}

Marine ecosystems are increasingly contaminated through multifarious man-made activities such as the discharge of sewage and industrial effluents into the ocean. This has resulted into drastic reduction of shallow waters fish populations and invertebrates, ecological imbalance resulting into large scale disappearance of numerous flora and fauna, increased pollution of marine with chemicals and toxins which affect the microbial populations [1]. The microbiota of bivalve mollusca have been thoroughly investigated since mussels may concentrate pathogenic microorganisms in their tissues and as such cause diseases to humans through their consumption [1]. However, the South African Molluscan Shellfish Monitoring and Control Programme is working tremendously with the shellfish farmers, laboratories, National Regulator for Compulsory Specification (NRCS), Department of Health (DoH) and Municipalities to enforces microbiological monitoring in commercial shellfish farms in order to minimize the risk of disease and poisoning through consumption of molluscan shellfish [2].

The outbreaks of infections have been attributed to bacterial and viral agents that are associated either with human wastes disposed to the ocean or bacterial pathogens indigenous to coastal marine environments [3]. Besides accumulating naturally occurring microorganisms and other pathogenic microorganisms, these shellfish are also prone to contamination by toxin-producing dinoflagellates, faecal pathogens especially the species of Salmonella, Shigella, Campylobacter, Listeria, Escherichia coli, Plesiomonas shigelloides and enteric viruses from sewage-polluted waters [3]. Thus, the international Commission on Microbial Specification for Foods have rated raw molluscan shellfish as the second highest hazard of all foods [4].

Perna perna (L.) is one of the economically and commercially important marine bivalves found along the south and east coast of South Africa [5]. The species naturally inhabits rocky shores along the coast and adjacent to estuaries that are increasingly contaminated with anthropogenic chemicals. It is harvested as a food source for its nutritional values. Along with the benefits derived from the consumption of Perna perna however, comes the potential risk of contamination. The harmful effect of the presence of the pathogenic microorganisms is augmented by the fact that Perna perna are consumed raw or under-cooked which may not completely ensure the inactivation of microbes or toxins, thereby creating a critical concern in terms of food safety [6]. Perna perna (L.) was chosen for this study because of its abundance and wide distribution along the east coast of South Africa, also it is commonly exploited for subsistence consumption [7].

Scientists have reported that the frequency of antibiotic resistance in bacteria from seafoods has significantly increased. The current treatment of infections caused by these bacteria should be reexamined as the severity of these infections makes antibiotic resistance in bacteria a critical public health concern $[8,9]$. The worldwide emergence of multi-drug resistant bacterial strains has rendered many of the current drugs used for treatment useless, causing treatment failures [10].

In South Africa, there is a dearth of information available on the bacterial pathogens isolated from Perna perna (L.) and their antibiotic susceptibility profiles. Therefore, the present study was undertaken to examine the presence of microorganism in the gut and gill of Perna perna as well as determining their susceptibility to important antimicrobial agents.

\section{Materials}

\section{Collection and samples preparation}

Grab sampling of Perna perna (L.) was carried out in which about 200-250 live organisms were collected into sterilized containers from Algoa Bay $\left(33^{\circ} 49^{\prime} 36^{\prime \prime}\right.$, 
2547'42"E), Port Elizabeth, Eastern Cape Province of South Africa. They were transported in cooler boxes on ice packs to the Microbiology Department Laboratory at the University of Fort Hare, Alice, for dissection and examination. Samples were sterilized with $70 \%$ ethanol and rinsed three times in order to remove the attached bacteria. Shells were then opened using a sterile scalpel blade. The shell liquor of the mussels was discarded and the gill and gut were removed, homogenized and aseptically transferred to sterile test tubes.

\section{Media used}

All the enrichment broth and media used in this study were obtained from Oxoid Ltd (UK).

\section{Bacteriological examination Enrichment cultures}

Twenty five grams ( $25 \mathrm{~g}$ ) of the homogenized gills and guts was inoculated into $225 \mathrm{ml}$ of the following selective enrichment broths for each isolates: Alkaline peptone water (Bacto peptone 1\%, $\mathrm{NaCl}$ 1\%) for Vibrio spp.; Tryptone soya broth with Casamino acids for Escherichia coli; Buffered peptone broth, Rappaport-Vassiliadis broth and Tetrathionate broth for Salmonella spp. pre-enrichment and selective enrichment steps respectively. Shigella broth to which novobiocin $(0.5 \mu \mathrm{g} / \mathrm{ml})$ had been added for Shigella spp.; Listeria Enrichment broth for Listeria spp. and Tryptic soy broth plus $10 \% \mathrm{NaCl}$ for Staphylococcus spp. Serial dilutions (up to $10^{-3}$ ) were made into the appropriate broth. All broths were incubated at $37^{\circ} \mathrm{C}$ for $24 \mathrm{~h}$ [11].

\section{Conventional culture method}

Aliquots of $0.2 \mathrm{~mL}$ of the $10^{-3}$ dilution from each of the enrichment medium was poured into the appropriate agar media plates as follows: Agar plates of Thiosulphate Citrate Bile Sucrose for Vibrio, Xylose lysine desoxycholate agar for Escherichia coli, Salmonella-Shigella agar for Salmonella, MacConkey agar for Shigella, PALCAM agar for Listeria and Baird-Parker agar for Staphylococcus. The plates were incubated at $37^{\circ} \mathrm{C}$ for $18-24 \mathrm{~h}$ [11]. Assay was carried out in three replicates.

\section{Isolation and identification}

Individual colonies from each agar media were randomly selected and sub-cultured. The plates were placed on a colony counter and the number of colony forming units was taken. The following tests were carried out on all the pure isolates: Gram staining, oxidase test strips (Oxoid, UK), catalase using $3 \%$ hydrogen peroxide $\left(\mathrm{H}_{2} \mathrm{O}_{2}\right)$. Analytical profile in$\operatorname{dex}$ (API) 20E and API staph system] (bio-Me'rieux, Marcy l'Etoile, France) were used for the identification [12].

\section{Scanning electron microscopy examination of the isolates}

For electron microscopy examination, the samples were coated with gold palladium and examined using JEOL JSM 6390 LV SEM at 15Kv (Japanese Electron Optical Lab.) Scanning Electron Microscope (SEM).

\section{Antimicrobial susceptibility profiling}

Susceptibility of the isolates against different antimicrobial agents was determined in vitro by employing the standardized agar disc-diffusion method according to Clinical and Laboratory Standards Institutes [13].

\section{Statistical analysis}

The experimental data was expressed as mean \pm standard deviation (SD) of the three replicates. Statistical analysis was done by using MINITAB program (version 17 for Windows) (Minitab Inc., Pennsylvania, USA). One-way analysis of variance (ANOVA) was used to compare the data in each sample among the isolates. $p<0.05$ was considered statistically significant. 
Table 1. Identification of bacterial isolates from Perna perna

\begin{tabular}{|c|c|c|c|c|c|c|}
\hline Shape & $\begin{array}{l}\text { Gram } \\
\text { reaction }\end{array}$ & $\begin{array}{l}\text { Oxidase } \\
\text { test }\end{array}$ & $\begin{array}{c}\text { Catalase } \\
\text { test }\end{array}$ & Colonial morphology & $\begin{array}{l}\text { API test } \\
(\%)\end{array}$ & Identification \\
\hline Curved rod & Negative & Positive & Positive & Yellow coloured colonies & 95 & Vibrio fluvialis \\
\hline Rod & Negative & Negative & Positive & $\begin{array}{l}\text { Pink colonies to red bile salt, precipitate } \\
\text { surrounding the colonies }\end{array}$ & 99.9 & Escherichia coli \\
\hline Rod & Negative & Negative & Positive & $\begin{array}{l}\text { Colourless with black centre, Light pink } \\
\text { colonies with distinct black centre }\end{array}$ & 99.9 & Salmonella spp. \\
\hline Rod & Negative & Negative & Positive & Smooth, colourless colonies & 95 & Shigella spp. \\
\hline Rod & Positive & Negative & Positive & Gray green surrounded by dark halo & 99.9 & Listeria monocytogenes \\
\hline Cocci & Positive & Negative & Positive & $\begin{array}{l}\text { Jet black colonies surrounded by clear } \\
\text { zone }\end{array}$ & 80 & Staphylococcus xylosus \\
\hline
\end{tabular}

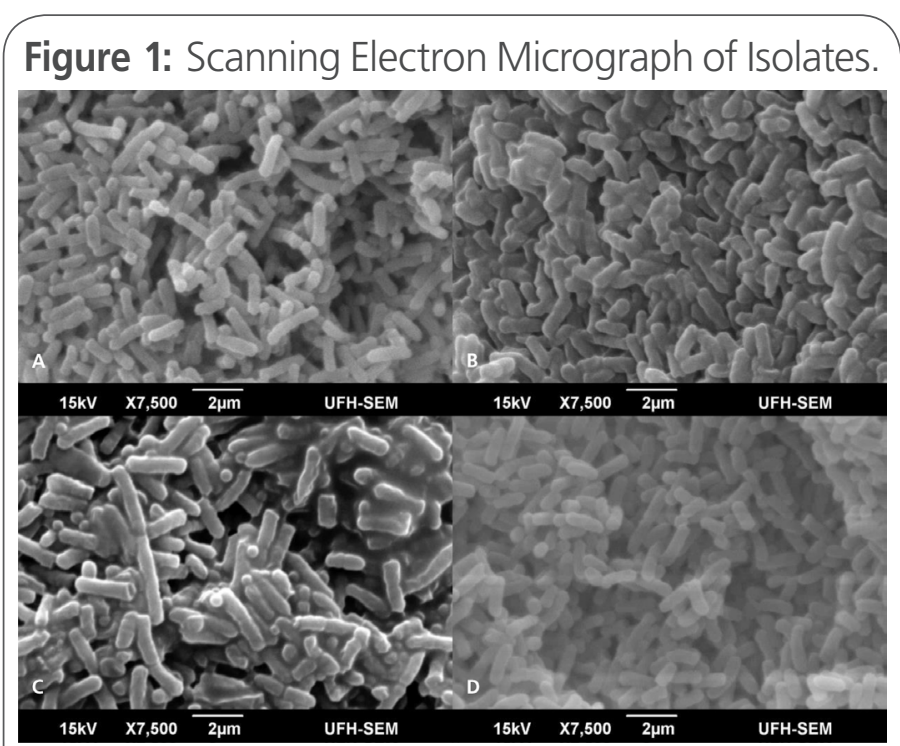

A) Curved rod shaped Vibrio cholerae; B) Rod-shaped Escherichia coli; C) Rod-shaped Salmonella spp.; D) Rod-shaped Shigella spp.

Figure 2: Scanning Electron Micrograph of Isolates.

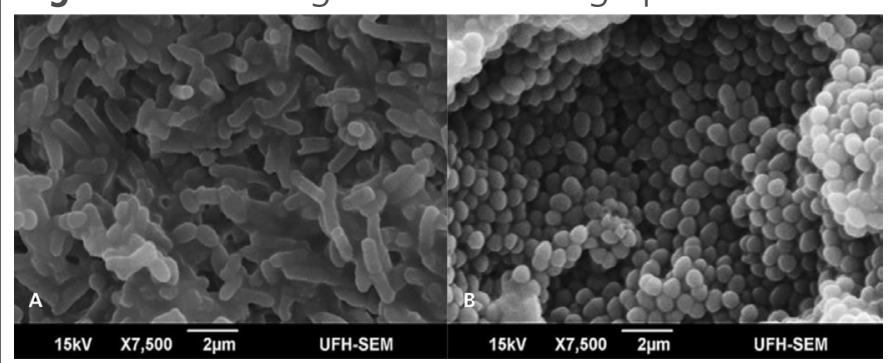

A) Rod-shaped L. monocytogenes; B) Grape-like cluster S. xylosus

\section{Results}

\section{Isolation and identification of bacteria in Perna perna}

In this study, six types of bacteria were isolated from Perna perna, identified and evaluated for their antimicrobial susceptibility profiling. The results indicated that four of the isolates were Gram-negative and two Gram-positive. Individual isolates from both the gill and gut had similar morphological shapes when observed under light and scanning electron microscopes. Four of the isolates were rod shaped, one curve shaped and one coccus shaped (Table 1, Figure 1-2). All were catalase positive, Vibrio spp. was oxidase positive while the remaining were oxidase negative. The bacterial isolates were identified with $>80 \%$ acceptable probability using analytical program interface identification system and the colonial characteristics of the isolates were equally noted. The microbial counts of $V$. fluvialis, E. coli, Salmonella spp., Shigella spp., S. xylosus and L. monocytogenes isolated from the gut and gill of Perna perna are significantly different $(p<0.05)$ as shown in Figure 3.

\section{Antibiotic susceptibility of the identified isolates}

The susceptibility and resistance patterns of the isolated bacteria are shown in Table 2 . The overall 
Table 2. Susceptibility pattern of the isolates against different antibiotics.

\begin{tabular}{|c|c|c|c|c|c|c|}
\hline \multicolumn{7}{|c|}{ Antibiotic susceptibility of isolates } \\
\hline Antimicrobial agent & V. cholerae & E. coli & Salmonella & Shigella & L.monocyctogenes & S. xylosus \\
\hline K & $\mathrm{R}$ & S & $S$ & $S$ & $\mathrm{R}$ & $\mathrm{R}$ \\
\hline AMP & - & $S$ & R & $\mathrm{R}$ & $\mathrm{R}$ & $\mathrm{R}$ \\
\hline NA & R & I & $S$ & $S$ & $\mathrm{R}$ & $\mathrm{R}$ \\
\hline CIP & - & S & S & $S$ & $S$ & S \\
\hline C & $S$ & S & $S$ & $S$ & $S$ & S \\
\hline TE & S & S & S & $S$ & $\mathrm{R}$ & S \\
\hline EFT & - & $S$ & S & S & $\mathrm{R}$ & $\mathrm{R}$ \\
\hline AK & - & $S$ & $S$ & $S$ & $\mathrm{R}$ & $R$ \\
\hline
\end{tabular}

Figure 3: Scanning Distribution of bacteria pathogens in the gut and gill of Perna perna (L.) collected from Algoa Bay. Data are presented as means \pm SD of three replicates. Bar graphs with different superscript are significantly difference $(P<0.05)$.

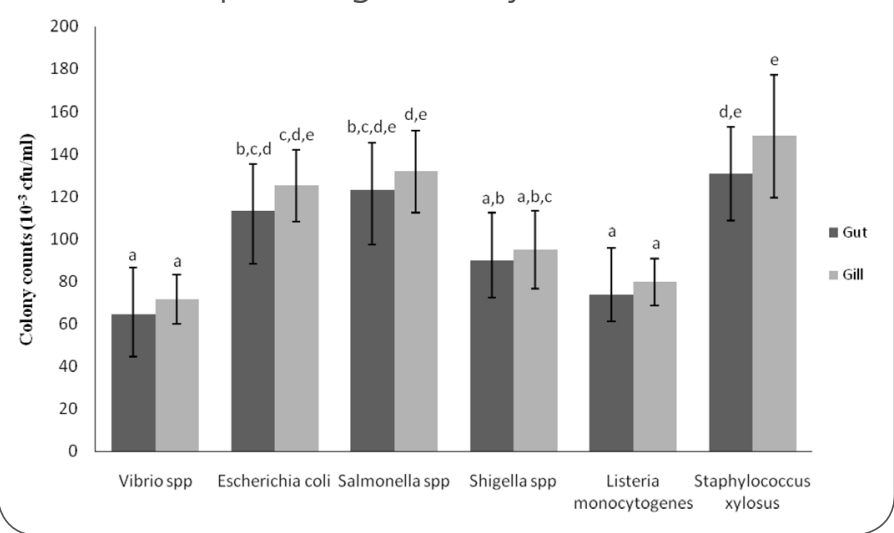

susceptibility of the isolates to antibiotics was $64 \%$ while resistance was 34\% with the rest being intermediate. Chloramphenicol, tetracycline and ciprofloxacin proved to be more effective than the other antimicrobial agents used in this study. Generally, the highest susceptibility was observed in chloramphenicol $21.4 \%$, followed by tetracycline and ciprofloxacin with $17.9 \%$ each while the lowest was seen in ampicillin. About $80 \%$ of the isolates showed resistance to ampicillin while none was resistant to ciprofloxacin and chloramphenicol.

\section{Discussion}

\section{Bacterial populations in the gill and gut of} Perna perna

The bacteria growth pattern in the samples show that Staphylococcus spp., was predominant; followed by Salmonella spp., E. coli, Shigella spp., L. monocytogenes and Vibrio spp., respectively. This finding agrees with previous report that shellfish are prone to contamination by faecal pathogen from polluted waters [14].

Several Vibrio species, native to both marine and estuarine environments have been identified as the causative agents of human illnesses in association of shellfish consumption [3]. Also, the occurrence of $E$. coli in shellfish has been encountered in different parts of the world [15], while the presence of Salmonella spp. in seafood and water cause salmonellosis, characterized by fever along with gastroenteritis, abdominal cramps and diarrhea [16]. These organisms are the leading causes of food-borne illnesses worldwide [17]. Shigella spp. have been isolated from shellfish and its infections manifested normally in watery, loose stools to more severe symptoms, including fever, abdominal pain, tenesmus and bloody diarrhea [17]. Shigella is important agent of diarrheal disease as it has a low infectious dose and long survival time in clams and oysters [18]. The 
low counts of L. monocytogenes and Vibrio spp. in this study confirmed the findings of Feldhusen [14] who observed that indigenous pathogenic bacteria are usually found at fairly low levels in fresh food samples. L. monocytogenes causes human disease called listeriosis and frequently related to seafood consumption [19]. Staphylococcus spp. possesses the ability to cause large scale foodborne disease outbreak through the consumption of shellfish [20].

\section{Antibiotic susceptibility of the isolates}

The increasing emergence of antibiotic-resistant pathogens associated with fish and shellfish is of major public health concern [21]. The overall susceptibility of the isolates to antibiotics was $64 \%$ while resistance was 34\% with the rest being intermediate. The isolates were mostly susceptible to chloramphenicol, tetracycline and ciprofloxacin. This finding agreed with a previous study carried out by Ahmed et al. [22] were Staphylococcus spp. was susceptible to ciprofloxacin, chloramphenicol and tetracycline isolates from fish belly. The incidence of Vibrio infections due to the consumption of raw or improperly cooked seafood has shown a sustained increase since 2000 in USA [23]. The first-line drugs including tetracycline and fluoroquinolones have remained highly effective against Vibrio spp. [24].

Both Shigella spp. and Salmonella spp. were susceptible to all the antibiotics used in this study except ampicillin, against which resistance was recorded. The sensitivity of enteric Salmonella spp. to these antibiotics have been observed in different regions of India [24]. L. monocytogenes isolate in this study was found to be susceptible to antibiotics that can be used to treat individuals with Listeriosis. In addition, a combination of ampicillin and aminoglycoside can be also used for treatment of listeriosis [25].

About $80 \%$ of our isolates showed resistance to ampicillin while none was resistant to ciprofloxacin and chloramphenicol. In recent years, resistance to ampicillin is often observed in bacterial isolates from marine environments [26]. The present study indicates that bacteria isolated were resistant to more than one antibiotic (Table 2). This result shows that spread of multidrug-resistant isolates in seafood will be of great concern for public health [27].

\section{Conclusion}

The present study revealed that there are bacterial pathogens in the gut and gill of shellfish which may pose health risk to the consumers if eaten raw or slightly cooked. The presence of these bacterial pathogens is often due to see pollution with human and animal sewage. The study also reveals that some of the bacterial isolates were multidrugresistant.

\section{Acknowledgments}

This study was supported by Govan Mbeki Research Development Council, University of Fort Hare. We wish to acknowledge South African Institute for Aquatic Biodiversity (SAIAB) for assistance with collection of samples. Special thanks to Dr. Francesca Pori for her help with identification and dissection of samples.

\section{Conflict of interests}

The authors declared no conflict of interests.

\section{References}

1. Aronson RB, Thatje S, McClintock JB, Hughes KA. Anthropogenic impacts on marine ecosystems in Antarctica. Ann N Y Acad Sci 2011;1223(1):82-107.

2. Department of Agriculture, Forestry and Fisheries. South African Molluscan Shellfish Monitoring and Control Programme. 2011. Available from: http://www.nda.agric.za/doaDev/sideMenu/ fisheries/03 areasofwork/Aquaculture/SAMSMCP/2011\%20 SMP\%20Report.pdf [Accessed 24 October 2017].

3. Iwamoto M, Ayers T, Mahon BE, Swerdlow DL. Epidemiology of seafood-associated infections in the United States. Clin Microbiol Rev 2010; 23:399-411. 
4. Department of Agriculture, Forestry and Fisheries. South African Molluscan Shellfish Monitoring and Control Programme (Issue 3, 2012). Available from: http://www.nda.agric.za/doaDev/ sideMenu/fisheries/03 areasofwork/Aquaculture/SAMSMCP/ SMP\%20Final\%2020120116.pdf [Accessed 24 October 2017].

5. Global Invasive Species Database. Perna perna (mollusc) Available from: http://www.iucngisd.org/gisd/species. php?sc=742 [Accessed 26 October 2017].

6. Jones S. Microbial contamination and shellfish safety. In: Shellfish safety and quality, Shumway, S.E. and G.E. Rodrick, (Eds). Elsevier 2009; pp: 3-28.

7. Baust S, Teh L, Harper S, Zeller D. South Africa's Marine Fisheries Catches. Fisheries Centre Research Reports. 1950-2010. University of British Columbia, Vancouver (Canada).

8. National Oceanic and Atmospheric Administration, 2009. Antibiotic Resistance: A Rising Concern In Marine Ecosystems.

9. Fallah AA, Saei-Dehkordi SS, Mahzounieh M. Occurrence and antibiotic resistance profiles of Listeria monocytogenes isolated from seafood products and market and processing environments in Iran. Food control 2013; 34:630-636.

10. Hancock RE. Mechanisms of action of newer antibiotics for Gram positive pathogens. Lancet Infect Dis 2005; 5:209-218.

11. United State Food And Drug Administration. Bacteriological Analytical Manuel Online (BAM) 2013.

12. Topi囚 PN, Coz-Rakovac R, Strunjak-Perovicl. Commercial phenotypic tests (API 20E) in diagnosis of fish bacteria: a review. Veterinarni Medicina 2007;52: 49-53.

13. Clinical and Laboratory Standards Institutes. Performance Standards for Antimicrobial Susceptibility Testing; Seventeenth Informational supplement 2007; 27: 1.

14. Feldhusen $F$. The role of seafood in bacterial foodborne diseases. Microbes Infect 2000; 2:1651-1660.

15. Van TTH, Chin J, Chapman T, Tran LT, Coloe PJ. Safety of raw meat and shellfish in Vietnam: an analysis of Escherichia coli isolations for antibiotic resistance and virulence genes. Inter J of Food Microbiol 2008; 124(3):217-223.

16. Brands DA, Inman AE, Gerba CP, Maré CJ, Billington SJ, Saif LA et al. Prevalence of Salmonella spp. in oysters in the United States. Appl Environ Microbiol 2005; 71:893-897.

17. Scallan E, Hoekstra RM, Angulo FJ, Tauxe RV, Widdowson MA, Roy SL, Jones JL, Griffin PM. Food-borne illness acquired in the United States-major pathogens. Emerg infect Dis 2011;17: 7.

18. Auerbach PS, Cushing TA, Harris NS. Auerbach's Wilderness Medicine E-Book. Marine Medicine. Elsevier Health Sci 2016; 1785-1777.

19. Butt $A A$, Aldridge $K E$, Sanders $C V$. Infections related to the ingestion of seafood Part I: Viral and bacterial infections. The Lancet infect Dis 2004; 4:201-212.

20. Croci L, Suffredini E. Rischiomicrobiologicoassociato al consumodiprodottiittici. Annali dell' IstitutoSuperiore di Sanità 2003;39(1): 35-46.
21. Bansemir A, Blume $M$, Schröder S, Lindequist U. Screening of cultivated seaweeds for antibacterial activity against fish pathogenic bacteria. Aquaculture.2005.11.051

22. Ahmed A, Rab A, Khan F, Qasim M. Identification and antibiotic Susceptibility of bacterial pathogens in rainbow trout at Juglote, Gilgit, Baltistan. Punjab Univ J Zool 2001; 26:135-139.

23. Center for Disease Control and Prevention. Preliminary FoodNet data on the incidence of infection with pathogens transmitted commonly through food-10 states. Morb and Mortal Wkly Rep 2007; 56:336-339.

24. Mandal S, Mandal MD, Pal NK. Antibiotic resistance of Salmonella enterica serovar Paratyphi A in India: emerging and re-emerging problem. J Postgrad Med 2006; 52: 163-166.

25. Aras Z, Ardıç M. Occurrence and antibiotic susceptibility of Listeria species in turkey meats. Korean J Food Sci Animal Resources 2015;35:669.

26. Wang C, Dang H, Ding Y. Incidence of diverse integrons and $\bigotimes$-lactamase genes in environmental Enterobacteriaceae isolates from Jiaozhou Bay, China World J Microbiol Biotechnol 2008; 24:2889-2896.

27. Cabello FC. Heavy use of prophylactic antibiotics in aquaculture: a growing problem for human and animal health and for the environment. Environ. Microbiol 2006; 8: 1137-1144.

\section{Publish in The International}

Arabic Journal of Antimicrobial Agents

The Journal is an open access peer-reviewed journal that publishes scientific papers about all aspects of antimicrobials. The journal will publish original research articles, reviews, brief reports and case reports dealing with basic and clinical antibacterial agents, antiviral, antiprotozoals, antituberculuous, antifungal and antihelminthes agents. All manuscripts must be prepared in English, and are subject to a rigorous and fair peer-review process. Accepted papers will immediately appear online. The journal aims to advance the knowledge, attitude and the research of chemotherapy in the Arabic world in cooperation with international, national scientific and public societies as well as research centers with similar aims and objectives. 